\title{
Medication-Induced Lesion in A Young Woman Mimicking Malignancy: Linear-Extended Esophageal Ulcer Due to Tetracycline Usage
}

\section{Genç Bir Kadında Maligniteyi Taklit Eden İlaç Kaynaklı Lezyon: Tetrasiklin Kullanımına Bağlı Doğrusal Genişlemiş Özofagus Ülseri}

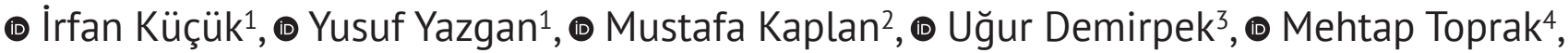
๑ Fatih Özçelik ${ }^{5}$

${ }^{1}$ University of Health Sciences Turkey, Sultan 2. Abdulhamid Han Training and Research Hospital, Clinic of Gastroenterology, Istanbul, Turkey

${ }^{2}$ University of Health Sciences Turkey, Sultan 2. Abdulhamid Han Training and Research Hospital, Clinic of Internal Medicine Istanbul, Turkey

${ }^{3}$ Bursa City Hospital, Clinic of Medical Microbiology, Bursa, Turkey

${ }^{4}$ University of Health Sciences Turkey, Sultan 2. Abdulhamid Han Training and Research Hospital, Clinic of Pathology Istanbul, Turkey

${ }^{5}$ University of Health Sciences Turkey, Sultan 2. Abdulhamid Han Training and Research Hospital, Clinic of Biochemistry Istanbul, Turkey

Oral tetracycline-induced esophageal injury usually presents with physiological symptoms of esophageal narrowing. The most common location is at the level of the aortic arch, accounting for approximately $76 \%$ of all cases.

A 27-year-old woman was admitted to the gastroenterology department of our institute, complaining dysphagia, feeling of food impaction and severe retrosternal chest pain after two weeks treatment of tetracycline for acne vulgaris. She did not have any comorbidity and reported intermittent vomiting sometimes with coffee ground appearance. After excluding possible cardiac conditions as the cause of cardiac chest pain, upper gastrointestinal endoscopy was performed and it revealed hyperemic antral gastropathy. At $30 \mathrm{~cm}$ from the incisors, a linear and vertically extended esophageal ulcer resembling a malignant lesion was observed.

Esophageal ulcers, which can show various symptoms and can be confused with cancers, may occur due to the use of oral tetracycline, although rarely. Therefore, patients' use of tetracycline should be questioned in clinical examination. To prevent such complications, patients should be advised to take tetracycline pills in an upright position with enough water.

Keywords: Tetracycline, esophagitis, malignancy

İlaca bağlı özofagus hasarı genellikle fizyolojik daralmalar düzeyinde ortaya çıkar. En yaygın yerleşim yeri, tüm olguların yaklaşık \%76'sını oluşturan aortik ark seviyesindedir. Yirmi yedi yaşında kadın hasta, akne vulgaris için tetrasiklin tedavisi sonrasında disfaji, yemek sıkışması hissi ve şiddetli retrosternal göğüs ağrısı şikayetleri ile enstitümüzün gastroenteroloji bölümüne başvurdu. Komorbiditesi yoktu ve bazen kahve telvesi görünümü ile birlikte aralıklı kusma bildirdi. Kardiyak göğüs ağrısının nedeni olası kardiyak durumlar dışlandıktan sonra, hiperemik antral gastropatiyi ortaya çıkaran üst gastrontestinal endoskopi yapıldı. Kesici dişlerden $30 \mathrm{~cm}$ uzaklıkta, malign bir lezyonu andıran lineer ve dikey olarak genişletilmiş bir yemek borusu ülseri gözlendi.

Tetrasiklin özofajitte özofagus ülserleri farklı şekillerde ortaya çıkabilir ve bazı nadir durumlarda ülserler yaygın ve şiddetli olabilir. Bazen iyi huylu özelliklerine rağmen karsinom gibi görünebilirler. Maligniteyi dışlamak için ülserlerden ve komşu mukozadan biyopsi alınmalıdır. Bu komplikasyonları önlemek için hastalara yeterli miktarda su ile dik pozisyonda tetrasiklin almaları önerilmelidir.

Anahtar Kelimeler: Tetrasiklin, özofajit, malignite

Address for Correspondence: Mustafa Kaplan, University of Health Sciences Turkey, Sultan 2. Abdulhamid Han Training and Research Hospital, Clinic of Internal Medicine İstanbul, Turkey

Phone: +90 5335672871 E-mail: dr_mustafakaplan@yahoo.com ORCID ID: orcid.org/0000-0002-0354-4762

Received: 14.04.2021 Accepted: 14.09.2021 


\section{Introduction}

Many tetracycline derivatives have been found to date from chlortetracycline discovered by Benjamin M. Duggar in 1948. There are preparations suitable for oral use. Tetracycline group antibiotics (doxycycline, tetracycline, and minocycline) are among the drugs that have important antiinflammatory properties as well as antibacterial activities. For this reason, it has been preferred by dermatologists in acute exacerbation of acne vulgaris, a chronic inflammatory disease of the pilosebaceous unit. It has also been found that its anti-inflammatory properties provide improvement in non-bacterial acne rosacea (1). However, despite all these features, esophageal ulcers have been reported, albeit rarely, due to tetracyclines, especially in young women. Often there are widespread ulcerations in one, sometimes several, esophageal segments that mimic esophageal cancer $(2,3,4)$. Drug-induced esophageal injury generally occurs at the level of physiologic narrowing. The most common location is at the level of the aortic arch, known as the retro-esophageal aortic segment. Injury here accounts for approximately $76 \%$ of all cases. Predominantly, it is encountered in women, due to using culprit medications such as tetracyclines and bisphosphonates. The incidence of pill esophagitis is $3.9 / 1000000$ per year. The mean age of the patients is 41.5 years (2). It generally has a benign prognosis.

\section{Case Report}

A 27-year-old woman was admitted to gastroenterology department of our institute, complaining dysphagia, feeling of food impaction and severe retrosternal chest pain after two weeks treatment of tetracycline for acne vulgaris. She did not have any comorbidity and reported intermittent vomiting sometimes with coffee ground appearance. No other abnormal condition was found in radiology, hematology, and biochemical tests. CK-MB and troponin I tests performed due to the patient's retrosternal pain were within normal limits. After excluding possible cardiac conditions as the cause of severe retrosternal chest pain, upper gastrointestinal endoscopy was performed and it revealed hyperemic antral gastropathy. At about $29 \mathrm{~cm}$ from the incisors, a linear and vertically extended esophageal ulcer resembling a malignant lesion was observed. It was $1 \mathrm{~cm}$ in width and $5 \mathrm{~cm}$ in length (Figure 1). Normal esophageal mucosa was observed from the incisors to the ulcer area.

The ulcer was covered with a clean white exudate and included focal hemorrhagic spots explaining the intermittent bloody vomiting. Adjacent mucosa near the ulcer margin was completely normal and the appearance of the rest of the esophagus was unremarkable. Histopathological examination of the endoscopic biopsy from the edges and center of the esophageal ulcer specimen revealed a dense acute inflammatory infiltrate with no evidence of neoplasia or infectious cause. Eosinophilic infiltration was also noteworthy in histopathologic report (Figure 2).

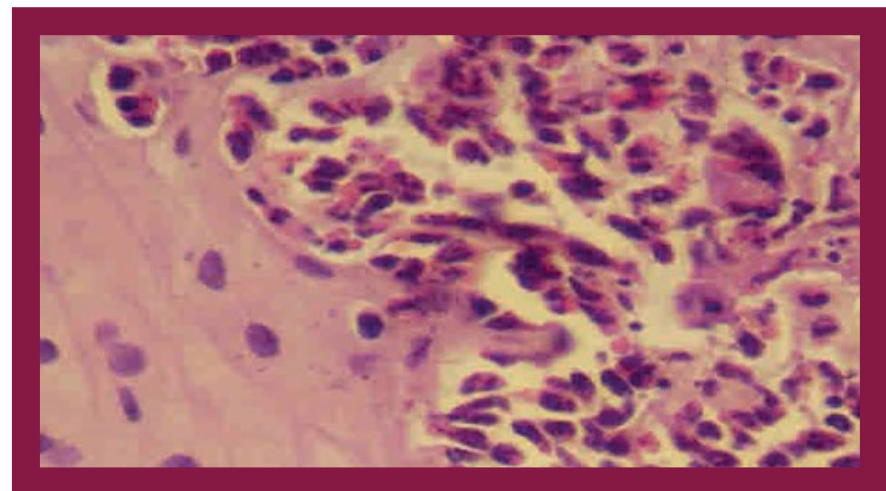

Figure 2. Acute inflammation with eosinophilic infiltration

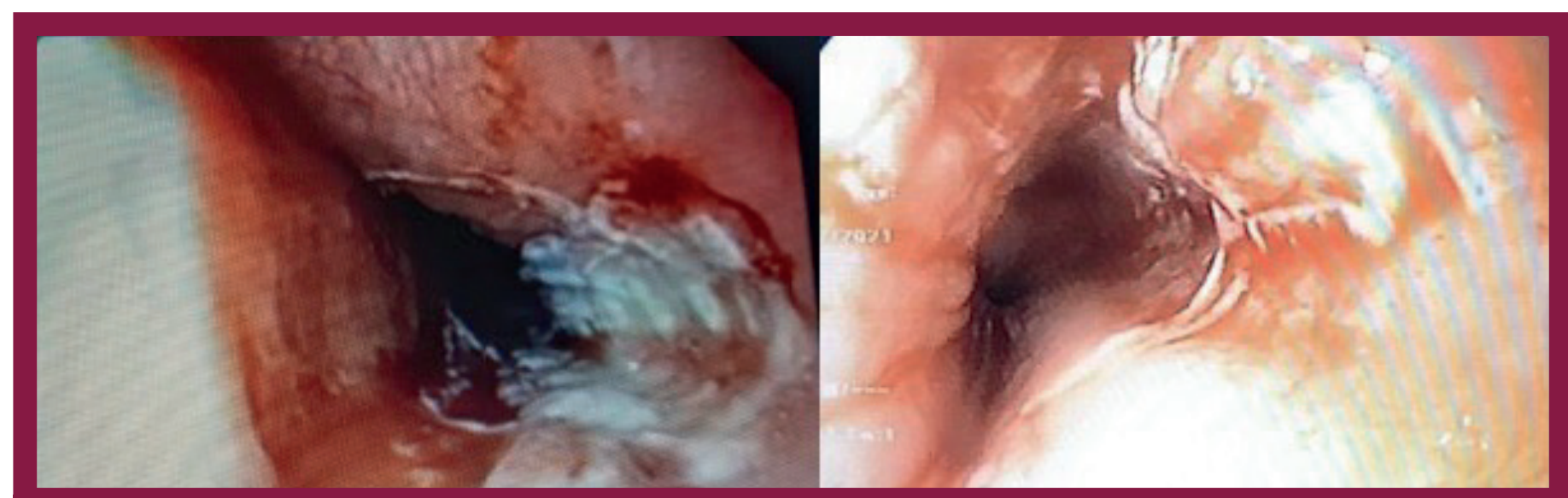

Figure 1. Tetracycline induced esophagitis in distal esophagus 
The patient's symptoms improved within 10 days with a liquid diet, sucralfate suspension, and proton pump inhibitor treatment. In addition, written consent was obtained from the patient.

\section{Discussion}

Tetracyclines have been used to treat gram-positive and gram-negative bacteria in general, as well as intracellular chlamydia, mycoplasmas, rickettsia, protozoan parasites, and various non-bacterial infections. It is an important option against bacteria that can be used in biological weapons. Because of all these properties, it is one of the most prescribed antibiotics in the world. Doxycycline is one of the most active tetracyclines and is the most preferred one in clinical use $(3,5)$. The clinical area where tetracyclines are most used is acne vulgaris, which is the most common skin disease in adolescence and can have negative emotional consequences. Acne can be acute or chronic. Sometimes dramatically severe inflammation leads to permanent scarring, especially in the face or back area (6). For this reason, it is recommended to start acne treatment with tetracycline derivatives without delay. However, although extremely rare, esophageal lesions induced using tetracyclines have been reported. These lesions are mostly in the form of mild esophagitis and can sometimes be seen as benign ulcers. The reason for this complication has been shown to be taking medications just before bedtime with very little water (3,7). Another clinical pathology in which tetracyclines are frequently used is helicobacter pylori infection. Especially with the spread of clarithromycin resistance all over the world, quadruple therapy regimens containing tetracycline and bismuth citrate have been used extensively as an alternative to the triple standard treatment of $\mathrm{H}$. pylori infection (amoxicillin and clarithromycin and proton pump inhibitor), which has been used for many years $(8,9)$.

Tetracyclines can cause nausea-vomiting, diarrhea, dysphagia, glossitis, enterocolitis, esophagitis, maculopapular rash, urticaria, angioneurotic edema, anaphylaxis, erythema and photosensitivity, and blood urea elevation. Oral tetracycline-induced esophageal ulcer and esophageal injury are rare complications. Esophageal ulcer is not only seen in people taking tetracycline. A similar picture has been reported in drugs with quite different characteristics. When esophageal injuries were first described in 1970, caustic medicinal pills were blamed for the incident. Especially when the passage is delayed, it has been determined that pill esophagitis develops because this pill dissolves in the esophagus and releases its harmful content. When looking at the classes of drugs that cause esophagus damage in general, nonsteroidal anti-inflammatory drugs, tetracyclines, potassium chloride tablets, alendronate and other drugs are listed, respectively. Therefore, quite different drugs have been reported to cause esophageal injury. This type of injury, called pill esophagitis or injury to the esophagus caused by the pill, is common $(3,10,11)$. However, it has not been sufficiently reported. Esophagitis and ulcer frequency due to tetracycline increases by age (12). Comorbidities, esophageal motility disturbances (13) and altered esophageal anatomy also predispose to drug induced esophagitis. However, this patient was younger than usual, and she did not have any chronic diseases. The typical endoscopic appearance of pill-induced esophageal injury is generally a circumferential ulcer (2) but in this case, endoscopy revealed a linear extending ulcer. Although pill esophagitis and ulcers take place in externally compressed and in narrow parts of the esophageal lumen, sometimes they locate in wider parts like the distal third of esophagus as in this case. Another aspect of the ulcer in our case was its resemblance to a malignant lesion as reported previously $(3,14)$.

The incidence of drug-induced esophagitis is affected by the oral forms of the drug. Esophagitis is more common in capsule forms compared to tablets in the form of drugs due to easier adhesion to the esophagus surface. Doxycycline, an acidic drug, accumulates in the epithelium of the esophagus and can cause contact esophagitis due to focal contact. In the advanced stage, it may penetrate deeper with local cytochemical effects and cause ulceration in the esophagus mucosa $(2,13)$.

According to the opinion of Tahan et al. (3) all patients who present with chest pain, odynophagia and dysphagia should be questioned in terms of drug-induced esophagitis. In this way, drug-related morbidity can be reduced with precautions that can be taken beforehand. It was recommended that suspected patients be given information on how and when to take the drugs. In addition, it was recommended to swallow the drug with approximately $100 \mathrm{ml}$ of water and then sit in an upright position for a while.

Esophageal ulcers, which can show various symptoms and can be confused with cancers, may occur due to the use of oral tetracycline, although rarely. Therefore, patients' use of tetracycline should be questioned in clinical examination. To prevent such complications, patients should be advised to take tetracycline pills in an upright position with enough water.

\section{Ethics}

Informed Consent: Consent form was filled out by all participants.

Peer-review: Internally peer-reviewed.

\section{Authorship Contributions}

Surgical and Medical Practices: I.K.,Y.Y., U.D., M.T., Concept: I.K., Y.Y., U.D., M.T., Design: İ.K., M.K., F.Ö., Data Collection 
or Processing: I..K., Y.Y., Analysis or Interpretation: I.K., U.D., Literature Search: İ.K., Writing: I.K., M.K., F.Ö.

Conflict of Interest: No conflict of interest was declared by the authors.

Financial Disclosure: The authors declared that this study received no financial support.

\section{References}

1. Nelson ML, Levy SB. The history of the tetracyclines. Ann N Y Acad Sci. 2011;1241:17-32. [Crossref]

2. Kikendall JW, Friedman AC, Oyewole MA, Fleischer D, Johnson LF. Pillinduced esophageal injury. Case reports and review of the medical literature. Dig Dis Sci. 1983;28:174-182. [Crossref]

3. Tahan V, Sayrak H, Bayar N, Erer B, Tahan G, Dane F. Doxycycline-induced ulceration mimicking esophageal cancer. Cases J. 2008;1:144. [Crossref]

4. Gencosmanoglu R, Kurtkaya-Yapicier O,Tiftikci A,Avsar E, Tozun N, Oran ES. Mid-esophageal ulceration and candidiasis-associated distal esophagitis as two distinct clinical patterns of tetracycline or doxycycline-induced esophageal injury.J Clin Gastroenterol. 2004;38:484-489. [Crossref]

5. Roberts MC. Tetracycline therapy: update. Clin Infect Dis. 2003;36:462-467. [Crossref]
6. Gollnick HP, Zouboulis CC. Not all acne is acne vulgaris. Dtsch Arztebl Int. 2014:111:301-312.

7. Kadayifci A, Gulsen MT, Koruk M, Savas MC. Doxycycline-induced pill esophagitis. Dis Esophagus. 2004;17:168-171. [Crossref]

8. Kaplan M, Tanoglu A, Duzenli T, Tozun AN. Helicobacter pylori treatment in Turkey: current status and rational treatment options. North Clin Istanb. 2019;7:87-94. [Crossref]

9. de Boer WA, Driessen WM, Tytgat GN. Only four days of quadruple therapy can effectively cure Helicobacter pylori infection. Aliment Pharmacol Ther. 1995;9:633-638. [Crossref]

10. Comparison of side-effects of tetracycline and tetracycline plus nystatin. Report to the Research Committee of the British Tuberculosis Association by the clinical trials subcommittee. Br Med J. 1968;4:411-415. [Crossref]

11. Abid S, Mumtaz K, Jafri W, Hamid S, Abbas Z, Shah HA, et al. Pill-induced esophageal injury: endoscopic features and clinical outcomes. Endoscopy. 2005;37:740-744. [Crossref]

12. Hollis JB, Castell DO. Esophageal function in elderly man. A new look at "presbyesophagus". Ann Intern Med. 1974;80:371-374. [Crossref]

13. Hey H, Jørgensen F, Sørensen K, Hasselbalch H, Wamberg T. Oesophageal transit of six commonly used tablets and capsules. Br Med J (Clin Res Ed). 1982;285:1717-1719. [Crossref]

14. Karaahmet F, Coşkun Y, Erarslan E, Yuksel I. Extensive esophageal damage resembling carcinoma due to tetracycline intake. Endoscopy. 2013;45(Suppl 2)UCTN:E258. doi: 10.1055/s-0033-1344560. [Crossref] 